\title{
An Overview of Sociology of Translation: Past, Present and Future
}

\author{
Jing Zheng ${ }^{1}$ \\ ${ }^{1}$ School of Foreign Languages, North China Electric Power University, Beijing, China \\ Correspondence: Jing Zheng, School of Foreign Languages, North China Electric Power University, Beijing, \\ China. E-mail: zhengjing79@126.com
}

Received: May 4, 2017 Accepted: May 30, $2017 \quad$ Online Published: July 15, 2017
$\begin{aligned} & \text { doi:10.5539/ijel.v7n4p28 } \\ & \text { URL: http://doi.org/10.5539/ijel.v7n4p28 }\end{aligned}$

\begin{abstract}
Sociology of translation is a burgeoning paradigm in current translation studies and its momentum of development tends to maintain for a long time. This paper reviews the development of sociology of translation as well as major sociological theories applied in translation studies and reflects on some problems in current sociologically-informed translation studies with respect to terminology, subject of study and research model. This paper suggests that researches on sociology of translation should further clarify the object of study and systemize research methods. Meanwhile, more empirical research should be conducted on what translators actually do and say they do in the widest possible contexts of their professional practice to make sociology of translation a truly original and productive area of study.
\end{abstract}

Keywords: translation studies, sociology of translation, sociological theories

\section{Introduction}

Translation has been traditionally viewed as an interpretive activity: the relevance of translation lies in informing addressees of what someone else has said, written or thought (Gutt, 2000, p. 166; cf. 2000, pp. 209-211). However, the increased networking and interdependence of today's globalized world are exerting inevitably huge influences on the nature of the translator and translation. It is increasingly obvious that the profession of translator and the practice of translation are in a period of rapid change. As Gutt (2000, p. 166; cf. 2000, pp. 47-68, 215-220) observes, the term translation at present is increasingly used for communication that constitutes a descriptive use of language. Translation is not necessarily a reported speech but can be a new utterance of which the primary purpose is an independent statement about or reference to the subject matter itself. Translation is now often performative, productive and discursive. As a result, translation studies must use new frameworks to interrogate its own discourses and to develop broader views of translation in order to respond to pressures coming from inside and outside the field alike.

Since its rise in the 1960s, the discipline of translation studies seems inclined toward paradigmatic shifts, or "turns". This inclination is caused by both the nature of the discipline's subject and the structure of the discipline. The various shapes of communication which mold the issues dealt with in the realm of translation studies, from the very beginning of the discipline's establishment process, call for us to go beyond disciplinary boundaries (Wolf, 2012, p. 131). However, for a quite long period of time, the process of translation was supposed to be immune to external disturbances. The translator was expected to take a neutral standpoint and be invisible in the translation practice. Similarly, the translation was considered not subject to any impacts of social factors.

As the "cultural turn" in the 1990s views the object of translation studies as "text embedded within its network of both source and target cultural signs" (Bassnett \& Lefevere 1990, p. 12), the sociological turn of translation studies convicts that translation is a social practice. According to sociology of translation, any translation is inevitably bound up within social contexts because on the one hand, the act of translating is undeniably carried out by individuals in a social system; and on the other hand, the translation phenomenon is unavoidably implicated in social institutions, which greatly determine the selection, production, and distribution of translation, and, as a result, the strategies adopted in the translation itself. This paper will have a review of the development of sociology of translation studies, major sociological theories applied in translation studies and discuss some problems in current sociologically-informed translation studies with respect to terminology, subject of study and mode of research with a hope of shedding some lights on further studies of researchers who are interested in translation studies from the perspective of sociology. 


\section{Emergence of Sociology of Translation}

Holmes first proposed the concept of translation sociology or socio-translation studies in his paper The Name and Nature of Translation Studies presented in the Translation Section of the Third International Congress of Applied Linguistics, held in Copenhagen, 21-26 August 1972. When introducing function-oriented descriptive translation studies, Holmes said that "Pursuing such questions as which texts were (and, often as important, were not) translated at certain time in a certain place, and what influences were exerted in consequence, this area of research is one that has attracted less concentrated attention... Greater emphasis on it could lead to the development of a field of translation sociology." (Holmes, 2000, p. 177) However, the systematic study of translation from a sociological perspective didn't come up until the 1990s. In the past over two decades, a series of works contributed to the emergence of a "translation sociology" and brought about important insights into the construction of a public discourse on translation and the self-image of translators and especially into the translation process itself, among other central issues (Inghilleri, 2003, 2005; Buzelin, 2005, 2013; Wolf \& Fukari, 2007; Pym, Shlesinger, \& Simeoni, 2008).

The sociological turn marks paradigmatic changes in reflection on the reasons conditioning a translation process (Wolf, 2012, p. 130). Established approaches in sociology are employed as a starting point for sketching new horizons and for further developments in translation studies. These approaches are used to help explore the mechanisms underlying translation in larger social contexts in general and the social nature of translation in particular. The new conceptualization of translation as a social practice has brought about a variety of research fields which so far have been under-researched, such as institutions of translators' training, professional institutions and their impact on translation practices, working conditions, questions of ethics in translation, political aspects of translation, and many more (ibid, p. 133).

In the 2000s, the sociological turn became one of the most prominent translation studies fields of research and included diverse themes and theoretical paradigms (Baker, 2010). Several sociological theories have been applied to translation studies, among which Bourdieu's theory of social fields, Luhmann's social systems theory and Callon and Latour's actor-network theory are the most notable ones (Inghilleri, 2005; Buzelin, 2005; Tyulenev, 2011, 2012, 2012, 2013).

\section{Sociological Theories in Translation Studies}

\subsection{Bourdieu and Sociology of Translation}

In studies on language in society, Bourdieu is often seen as a macro-sociological theorist whose main contributions lie in the field of theorizing social action and structuration, symbolic power relations and capital, and habitus (Blommaert, 2005, p. 223). According to Bourdieu (1984), capital is accumulated labor which enables agents or groups of agents to appropriate social energy in the form of reified or living labor. Capital takes four fundamental forms: as economic capital, which is immediately and directly convertible into money and may be institutionalized in the forms of property rights; as cultural capital, which is convertible, on certain conditions, into economic capital and may be institutionalized in the forms of educational qualifications; as social capital, made up of social obligations ("connections"), which is convertible, in certain conditions, into economic capital and may be institutionalized in the forms of a title of nobility; and as symbolic capital, which designates the effects of any form of capital when people do not perceive them as such. Habitus is a system of embodied dispositions, tendencies that organize the ways in which individuals perceive the social world around them and react to it. These dispositions are usually shared by people with similar background in terms of social class, religion, nationality, ethnicity, education, profession etc. (Lizardo, 2004), as the habitus is acquired through mimesis and reflects the lived reality to which individuals are socialized, their individual experience and objective opportunities. A field is a setting in which agents and their social positions are located. The position of each particular agent in the field is a result of interaction between the specific rules of the field, agent's habitus and agent's capital (social, economic and cultural).

Bourdieu's concepts of habitus, field and capital have contributed greatly to the theorization of the interaction between agency and structure within translation studies. Within Bourdieu's theoretical framework, translators with their own habitus and capital compete in the field of power relations and thus practice translation. Bourdieu's conceptualization of the relationship between agency and structure has proved useful for addressing the reproductive or transformative potential of acts of translation within particular historical and socio-cultural contexts and the specific impact of translators and the complex of networks in which they operate on translation activities. 


\subsection{Callon and Latour's Actor-network Theory}

Research in French sociology of science has been dominated by two schools of thought represented by Pierre Bourdieu and Bruno Latour. The two schools which are generally taken as radically opposed to each other differ mainly in the importance placed on agency or, conversely, on structure. Whereas Bourdieu assumes that society can only be explained by analyzing practices and relating them to their authors' position in society as well as to their own trajectory, Latour claims that to understand a society one must, above all, analyze the way humans and non-humans interact, i.e., how the artefacts that circulate in this society (starting with scientific and technological ones) are produced (Buzelin, 2005).

According to Latour (1997), actor-networks encompass human and non-human actors, i.e., anything that can induce, whether intentionally or not, an action. Both human and non-human actors are treated equally according to the principle of generalized symmetry. Actor-network theory tries to explain how material-semiotic networks come together to act as a whole; the clusters of actors involved in creating meaning are both material and semiotic. As a part of this it may look at explicit strategies for relating different elements together into a network so that they form an apparently coherent whole. These networks are potentially transient, existing in a constant making and re-making (Latour, 2005). The theory assumes that nothing lies outside the network of relations and suggests that there is no difference in the ability of technology, humans, animals, or other non-humans to act (and that there are only enacted alliances). As soon as an actor engages with an actor-network it too is caught up in the web of relations, and becomes part of the entelechy.

In light of Latour's theory, translation is a heterogeneous network in which human actors such as translators and commissioners and non-human actors such as translation companies and paralleled texts interact with each other. By following the actors in the network of translation, i.e. observing the network as it builds, consolidates and transforms itself through the production process, translators' choice of translations as well as negotiations and decision-making that influence their choice can be observed.

\subsection{Luhmann's Social Systems Theory}

The core element of Luhmann's theory centers on the problem of the contingency of the meaning and thereby it becomes a theory of communication. Social systems are systems of communication, and society is the most encompassing social system. Being the social system that comprises all (and only) communication, today's society is a world society (Luhmann, 1982). A system is defined by a boundary between itself and its environment, dividing it from an infinitely complex, or (colloquially) chaotic, exterior. Furthermore, each system has a distinctive identity that is constantly reproduced in its communication and depends on what is considered meaningful and what is not. Social systems are self-reproducing and self-referential. Luhmann's theory is introduced to translation studies to discuss the nature of translation (Hermans, 1999) and the systematic study of translation (Tyulenev, 2011).

\section{Problems and Prospects of Sociology of Translation}

\subsection{Current Problems in Sociology of Translation}

With the deepening of sociological translation studies, some problems that may greatly hinder the future development of this paradigm of translation studies emerged. The first is about the terminology. Sociology of translation, translation sociology, socio-translation studies are terms used in different studies and in most cases can replace each other. Wolf $(2007$, p. 31) argues that the different terminologies used in current research are caused by the fact that studies in this paradigm is in the making. However, a unified term for studies in a certain academic field is of great importance. As this branch of research studies translation from the perspective of sociological theories, this paper asserts that sociology of translation is a more proper name than translation sociology. The latter may indicate the study subject is sociology, but the methods of study and theoretical basis are from translation studies.

The second problem in current sociology of translation studies is about its study subject. Wolf (2007, pp. 13-18) identifies three types of sociology of translation studies: sociology of agents, sociology of the translation process and sociology of the cultural product. As sociology of translation deals with the macro environment of translation activities, some researches question that its ignorance of language and text may make it deviate from the essence of translation studies. However, translation is a complicated social practice. Its study should not be confined to the study of language and text only but subject to a broader social context. On the one hand, sociology of translation focuses on social and cultural elements that influence the selection, production, and distribution of translation. On the other hand, it is also concerned with language conversion, text production and translation strategies. It advocates studying language, text and other micro questions in a macro context of field, 
system and network. In fact, to deny translation activity as a social phenomenon and repercussions of its social context on text production is a real deviation from translation studies. Sociology of translation is a comprehensive study of translation with strong theoretical support of micro-analysis, meso-analysis and macro-analysis of sociology.

The third problem is about its research model. Sociology of translation provides a brand-new perspective of studying translation. However, it is complained that sociological theories are too abstract to be applied in real-world translation studies. It can guide translation studies to a broader context but may fail to instruct translation practices in reality.

\subsection{Prospects of Sociology of Translation}

When describing the future directions of sociology of translation, Inghilleri $(2005$, p. 142) says "the emerging sociology of translation and interpreting will develop a certain eclecticism with respect to social theory or, indeed, establish divergent and competing approaches. Each of these possibilities suggests a future of innovative and energized dialogue and debate." It seems likely that the burgeoning branch of translation studies will continue its momentum of development in the future. Sociological translation studies needs to further clarify its object of study and systemize its research methods. Agency and language have to be examined specifically in sociological translation studies on the basis of full comprehension of sociological theories that are different and sometimes competing in certain aspects. The study of agency is of primary importance to make translation studies more "agent aware" and translators more visible as social actors. Therefore, more empirical research should be conducted on what translators actually do and say they do in the widest possible contexts of their professional practice.

\section{Conclusion}

Sociology of translation has come to the center stage of translation studies after over two decades of gradual development. Though this paradigm is prosperous in current translation studies, it also faces serious challenges in its further development such as terminology, object of study and research methods. To further develop sociologically-informed translation studies, researchers need to improve their knowledge on sociology and apply them accurately to studies on language and agency, as well as translators' professional practices. In a word, sociology of translation provides a new perspective to translation studies and enriches the theoretical framework of translation studies.

\section{Acknowledgements}

This research is funded by the Fundamental Research Funds for the Central Universities, No. JB2016094.

\section{References}

Baker, M. (Eds.). (2010). Critical Readings in Translation Studies. London and New York: Routledge.

Bassnett, S., \& André, L. (1990). Introduction: Proust's Grandmother and the Thousand and One Nights: The “Cultural Turn" in Translation Studies. In S. Bassnett \& L. André (Eds.), Translation, History and Culture (pp. 1-13). London and New York: Pinter.

Blommaert, J. (2005). Bourdieu the Ethnographer. The Translator, 11(2), 219-236. https://doi.org/10.1080/13556509.2005.10799199

Bourdieu, P. (1977). Outline of a Theory of Practice. Cambridge: Cambridge University Press. https://doi.org/10.1017/CBO9780511812507

Bourdieu, P. (1984). Distinction: A Social Critique of the Judgment of Taste (In R. Nice, Trans.). Cambridge, Mass.: Harvard University Press.

Buzelin, H. (2005). Unexpected Allies. The Translator, 11(2), $193-218$. https://doi.org/10.1080/13556509.2005.10799198

Buzelin, H. (2013). Sociology and Translation Studies. In C. Millán \& F. Bartrina (Eds.), The Routledge Handbook of Translation Studies (pp. 186-200). London and New York: Routledge.

Gutt, E. A. (2000). Issues of Translation Research in the Inferential Paradigm of Communication. In M. Olohan (Ed.), Intercultural Faultlines: Research Models in Translation Studies I: Textual and Cognitive Aspects (pp. 161-179). Manchester: St. Jerome.

Gutt, E. A. (2000). Translation and Relevance: Cognition and Context. Manchester: St. Jerome.

Hermans, T. (1999). Translation in Systems: Descriptive and System-Oriented Approaches Explained. 
Manchester: St. Jerome.

Holmes, J. S. (2000). The name and nature of translation studies. In L. Venuti (Eds.), The Translation Studies Reader (pp. 172-185). New York and London: Routledge.

Inghilleri, M. (2003). Habitus, Field and Discourse. Interpreting as a Socially Situated Activity. Target, 15(2), 243-268. https://doi.org/10.1075/target.15.2.03ing

Inghilleri, M. (2005). The Sociology of Bourdieu and the Construction of the "Object" in Translation and Interpreting Studies. The Translator, 11(2), 25-145. https://doi.org/10.1080/13556509.2005.10799195

Inghilleri, M. (Eds.). (2005). Bourdieu and the Sociology of Translation and Interpreting. The Translator, 11(2).

Latour, B. (1997). On Actor-Network Theory. A Few Clarifications. Retrieved from http://amsterdam.nettime.org/Lists-Archives/nettime-1-9801/msg00019.html

Latour, B. (2005). Reassembling the Social: An Introduction to Actor-Network-Theory. Oxford: Oxford University Press.

Lizardo, O. (2004). The cognitive origins of Bourdieu's Habitus. Journal for the Theory of Social Behaviour, 34(4), 375-448. https://doi.org/10.1111/j.1468-5914.2004.00255.x

Luhmann, N. (1982). The World Society as a Social System. International Journal of General Systems, 8(3), 131-138. https://doi.org/10.1080/03081078208547442

Pym, A., Shlesinger, M., \& Simeoni, D. (Eds.). (2008). Beyond Descriptive Translation Studies. Investigations in Homage to Gideon Toury. Amsterdam: John Benjamins. https://doi.org/10.1075/btl.75

Tyulenev, S. (2011). Applying Luhmann to Translation Studies: Translation in Society. New York and London: Routledge.

Tyulenev, S. (2012). Systemics and Lifeworld of Translation. In L. Foran (Eds.), Translation and Philosophy (139-155). Frankfurt am Main: Peter Lang.

Tyulenev, S. (2012). Translation and the Westernization of Eighteenth-Century Russia: A Social-Systemic Perspective. Berlin: Frank \& Timme.

Tyulenev, S. (2013). Translating in the Public Sphere: Birth Pangs of a Developing Democracy in Today's Russia. SALALS. Special Issue: Translation in Developmental Contexts, 31(4), 469-479. https://doi.org/10.2989/16073614.2013.864443

Wolf, M. (2012). The Sociology of Translation and Its “Activist Turn”. Translation and Interpreting Studies, 7(2), 129-143.

Wolf, M., \& Alexandra, F. (Eds.). (2007). Constructing a Sociology of Translation. Amsterdam: John Benjamins. https://doi.org/10.1075/btl.74

\section{Copyrights}

Copyright for this article is retained by the author(s), with first publication rights granted to the journal.

This is an open-access article distributed under the terms and conditions of the Creative Commons Attribution license (http://creativecommons.org/licenses/by/4.0/). 